\title{
SYSTEMATIC REVIEW: PELAYANAN INTERVENSI KEPERAWATAN JIWA PADA LANSIA DI MASYARAKAT
}

\section{MENTAL HEALTH NURSING INTERVENTION TO ELDERLY IN COMMUNITY : SYSTEMATIC REVIEW}

\author{
Erwin Yektiningsih \\ STIKes Pamenang \\ Korespondensi Penulis : erwiny.parefortune@gmail.com
}

\begin{abstract}
Abstrak
Latar Belakang: Perbaikan pelayanan kesehatan telah memberikan pengaruh terhadap menurunnya angka kematian bayi dan anak, yang berdampak pada meningkatnya usia harapan hidup, sehingga terjadi peningkatan proporsi lansia di masyarakat dengan memberikan pelayanan keperawatan jiwa pada lansia di komunitas melalui berbagai pendekatan bisa di upayakan untuk meningkatkan derajat kesehatan.

Tujuan : Sistematik review ini bertujuan untuk mengidentifikasi pelayanan intervensi keperawatan jiwa pada lansia yang dapat diaplikasikan di pelayanan kesehatan masyarakat.

Methode : Sistematik review ini dimulai dengan mengidentifikasi literatur pada artikel ilmiah yang telah dipublikasikan antara tahun 2014-2020 di database internasional di PubMed, Scient Direct, di Google Scholar. Pencarian juga dilakukan melalui google search dan juga portal $e$ resource di Indonesia. Seleksi dilakukan dengan PRISMA flowdiagram. Setelah diperoleh 14 artikel yang relevan untuk dianalisis menjadi sistematik review.

Hasil : Lansia dapat diberikan intervensi keperawatan jiwa di masyarakat seperti upaya mengatasi stress (olah raga, SGT, reminiscence group therapy, art therapy), terapi kelompok teraupeutik (singging grup, Assertive community treatment, laughter therapy program, terapi beapreasi, latihan keseimbangan, relaksasi progresif, dzikir, permaian halma), sehingga di harapkan lansia dapat meningkatkan kesejahteraan psikologi untuk meningkatkan derajat kesehatan lansia dengan dukungan penuh dari masyarakat.

Kesimpulan: Berdasarkan fakta tersebut dapat dapat di terapkan secara efektif untuk penatalaksanaan kesehatan jiwa pada lansia di lingkup masyarakat secara empiris reliabel dan handal.
\end{abstract}

Kata kunci : keperawatan jiwa, lansia, masyarakat

\section{Abstract}

Background: Health services improvement has been giving to impact infant and child mortality decrease, increasing life expectancy, that's resulting increase proportion of the elderly in community with providing mental health nursing for elderly in the community services by various approaches can be attempted to improve health status.

Objective: This systematic review aims to identify mental health nursing intervention services for the elderly that can be applied in public health services.

Method: This systematic review was begun by identifying literature that scientific articles published between 2014-2020 in the international database on PubMed, Scient Direct. So Searching was done by the international database as google scholar google search and also eresource portals in Indonesia. The selection was done by PRISMA flow diagram. The relevant articles 14 were obtained for analysis into a systematic review.

Results: Elderly can be given by mental health nursing interventions in the community such as efforts to cope with stress (exercise, SGT, reminiscence group therapy, art therapy), therapeutic group therapy (singing group, Assertive community treatment, laughter therapy program, beapreasi therapy, balance training, relaxation). progressive, dhikr, halma games), that elderly was hoped to improve psychological well-being to increase the health status of elderly with full support from the community. 
Conclusion: Based on these facts, it can be applied effectively for mental health management in the elderly in the community, empirically reliable and reliable.

Keywords: mental health nursing, elderly, community

\section{Pendahuluan}

Perbaikan pelayanan kesehatan telah memberikan pengaruh terhadap menurunnya angka kematian bayi dan anak, meningkatnya usia harapan hidup, sehingga terjadi peningkatan proporsi lansia di masyarakat (Rusdi, 2013) Menurut WHO lansia adalah kelompok penduduk yang berumur 60 tahun atau lebih. Secara global pada tahun 2013 proporsi dari populasi penduduk berusia lebih dari 60 tahun adalah 11,7\% dari total populasi dunia dan diperkirakan jumlah tersebut akan terus meningkat seiring dengan peningkatan usia harapan hidup. Data WHO menunjukan pada tahun 2000 usia harapan hidup orang didunia adalah 66 tahun, pada tahun 2012 naik menjadi 70 tahun dan pada tahun 2013 menjadi 71 tahun. Jumlah proporsi lansia di Indonesia juga bertambah setiap tahunnya. Data WHO pada tahun 2009 menunjukan lansia berjumlah $7,49 \%$ dari total populasi, tahun 2011 menjadi 7,69\% dan pada tahun 2013 didapatkan proporsi lansia sebesar 8,1\% dari total populasi (WHO, 2013). Menjadi lansia merupakan suatu permasalahan tersendiri dan setiap orang mungkin menghindarinya karena merasa tidak nyaman dengan gejala penuaan proses degenerasi telah membuat lansia mengalami berbagai masalah kesehatan \& penyakit yang berefek pada kesehatan jiwanya (Rusdi, 2013). Kesehatan mental atau kesehatan jiwa merupakan aspek penting dalam mewujudkan kesehatan secara menyeluruh. Kesehatan mental juga penting diperhatikan selayaknya kesehatan fisik. There is no health without mental health (WHO, 2013)

Permasalahan kesehatan jiwa dapat menyebabkan penderitaan yang berkepanjangan bagi individu, keluarga, masyarakat, dan negara salah satu strategi yang harus dilakukan adalah dengan memasukkan layanan kesehatan jiwa ke pelayanan primer (Fauzia and Paramita, 2016). Layanan kesehatan jiwa bersifat berkesinambungan dari komunitas ke rumah sakit dan sebaliknya, serta

strategi menggerakkan dan memberdayakan msyarakat untuk hidup sehat, memfasilitasi percepatan pencapaian derajat kesehatan setinggi-tingginya bagi seluruh penduduk dengan mengembangkan kesiap-siagaan di tingkat desa dengan masyarakat yang sadar mau dan mampu mencegah dan mengatasi berbagai ancaman yang sadar, mau dan mampu mencegah mengatasi berbagai ancaman terhadap kesehatan masyarakat (Keliat, Budi Anna, dkk 2010).

Keperawatan kesehatan komunitas sebagai tindakan untuk meningkatkan dan mempertahankan kesehatan dari populasi dengan menginterpretasikan ketrampilan dan pengetahuan yang sesuai dengan keperawatan dan kesehatan masyrakat dilakukan komperenhensif pada seluruh kelompok melalui pendekatan ilmu kesehatan masyarakat dan teori keperawatan professional yang bertujuan meningkatkan derajat kesehatan pada seluruh komunitas (Efendi, 2016) gangguan kesehatan mental di komunitas tidak bisa kita remehkan, karena jumlah kasusnya saat ini masih cukup mengkhawatirkan. Terdapat sekitar 450 juta orang menderita gangguan mental dan perilaku di seluruh dunia. Diperkirakan satu dari empat orang akan menderita gangguan mental selama masa hidup mereka (Ayuningtyas and Rayhani, 2018).

Sistem kesehatan di dunia dianggap belum cukup menanggapi beban gangguan mental, sehingga terdapat kesenjangan antara kebutuhan akan perawatan dan persediaannya yang sangat besar. Sekitar $85 \%$ orang dengan gangguan mental parah di negara berkembang tidak mendapat pengobatan atas gangguannya. Sejalan dengan ini juga diketahui bahwa pengeluaran setahun bagi kesehatan mental masih rendah yaitu kurang dari US\$ 2 per orang, serta tenaga kesehatan mental yang kurang dari 1 per 100.000 populasi (WHO, 2013; Ayuningtyas \& Rayhani, 2018).

Telah banyak studi penelitian menggunakan intervensi pelayanan intervensi keperawatan jiwa masyarakat pada lansia untuk meningkatkan derajat kesehatannya dengan memberikan intervensi keperawatan komperehensif yang sesuai di komunitas namun perlu di kaji lebih dalam mengenai berbagai intervensi keperawatan jiwa yang 
sesuai di dapat di aplikasikan efektif di masyarakat, maka tujuan dari sistematik review ini adalah untuk mengetahui," Apa saja pelayanan intervensi keperawatan jiwa pada lansia di masyarakat ?".

\section{Metode}

\subsection{Pertanyaan Penelitian Pertanyaan penelitian pada review}

Pertanyaan penelitian pada review ini adalah," Apa saja pelayanan intervensi keperawatan jiwa pada lansia di masyarakat ?"

\subsection{Identifikasi jurnal yang relevan dari judul / abstrak}

Identifikasi jurnal dilalukan dengan mencari artikel jurnal yang telah dipublikasikan pada tahun 2014-2020 di databes internasional, seperti PubMed, Scient Direct, Google Scholar. Pencarian di dilakukan dengan menggunakan kata kunci,"pelayanan kesehatan jiwa masyarakat pada lansia", community mental nursing health elderly" Referensi yang dipilih untuk sintesis harus memenuhi kriteria inklusi yaitu pelayanan kesehatan terhadap intervensi keperawatan jiwa pada lansia di lingkungan masyarakat.

\subsection{Skrining dan Eligibilitas kelayakan}

Artikel diperoleh sebanyak 3128 judul artikel di PubMed, 8454 judul artikel di Scient Direct, 15600 judul artikel di Google Scholar. Daftar artikel yang relevan dengan pertanyaan penelitian berhasil di identifikasi. Setelah di skrining melalui abstrak diperoleh 437 artikel relevan dengan pelayanan intervensi keperawatan jiwa pada lansia di masyarakat. Seleksi dilanjutkan dengan memilih jurnal yang relevan dengan pelayanan intervensi keperawatan jiwa pada lansia di masyarakat, 217 artikel layak (eligible) di dapatkan 32 qualitatif sedangkan 185 artikel quantitative, tetapi yang di keluarkaan karena termasuk kriteria ekslusi 171 artikel dan memiliki artikel duplikasi 4018 artikel. Pada tahap akhir ini hanya di dapatkan 14 artikel berisikan pelayanan intervensi jiwa masyarakat pada lansia

\subsection{Seleksi dan pemilihan dokumen}

Seleksi dan pemilihan dokumen dilakukan dengan diagram alur PRISMA dapat dilihat pada gambar 1. Ringkasan hasil penelitian tentang pelayanan intervensi keperawatan jiwa pada lansia di masyarakat dianalisa dari tahun $2014-2020$.

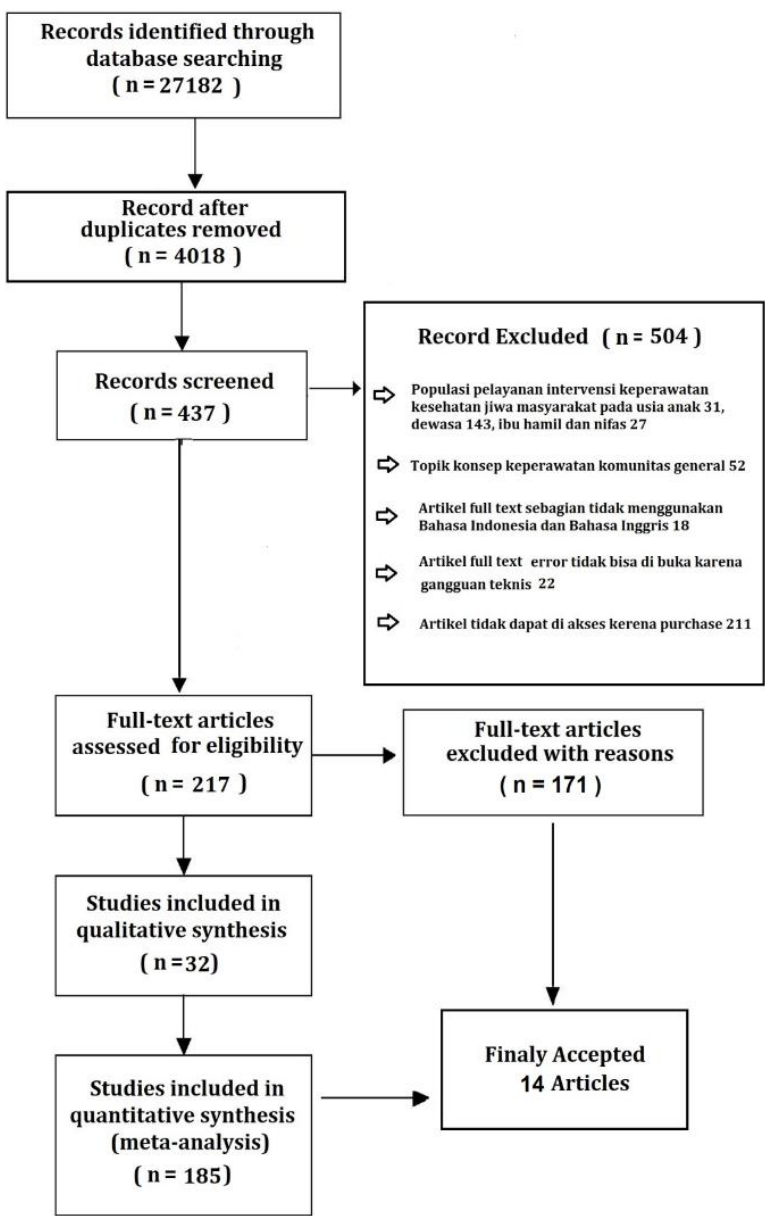

Gambar 1 Diagram alur PRISMA untuk mengidentifikasi literature pelayanan intervensi keperawatan jiwa pada lansia di masyarakat dari tahun 2014 - 2020 
Tabel 1 Ringkasan hasil penelitian tentang pelayanan intervensi keperawatan jiwa pada lansia di masyarakat dari tahun $2014-2020$

\begin{tabular}{|c|c|c|c|c|c|c|c|}
\hline $\begin{array}{l}\mathrm{N} \\
\mathrm{O}\end{array}$ & $\begin{array}{l}\text { Authors } \\
\text { \& year }\end{array}$ & Purpose & $\begin{array}{l}\text { Method } \\
\text { (design) }\end{array}$ & Sample & Intervention & $\begin{array}{l}\text { Data } \\
\text { Analysis }\end{array}$ & Major Findings \\
\hline 1 & 2 & 4 & 5 & 6 & 7 & 8 & 9 \\
\hline 1 & $\begin{array}{l}\text { Eriyono } \\
\text { Budi } \\
\text { Wijoyo, } \\
\text { dkk } \\
(2020) \\
\text { Indonesia }\end{array}$ & $\begin{array}{l}\text { Optimilisasi } \\
\text { integritas diri } \\
\text { melalui terapi } \\
\text { kelompok } \\
\text { teraupeutik } \\
\text { lansia }\end{array}$ & diskriptif & $\begin{array}{l}\mathrm{N}=1 \\
\text { orang } \\
\text { pada } \\
\text { lansia }\end{array}$ & $\begin{array}{l}\text { Terapi individu } \\
\text { dan terapi } \\
\text { kelompok } \\
\text { teraupeutik } \\
\text { (TKT) berjumlah } \\
6 \text { sesi dengan } 4 \\
\text { kali pertemuan }\end{array}$ & studi kasus & 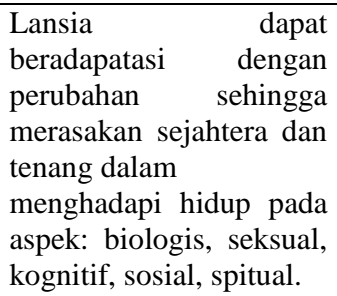 \\
\hline 2. & $\begin{array}{l}\text { Kurniawa } \\
\text { n, Ihsan } \\
\text { (2019) } \\
\text { Indonesia }\end{array}$ & $\begin{array}{l}\text { Hubungan } \\
\text { olahraga, } \\
\text { stress dan } \\
\text { pola makan } \\
\text { dengan } \\
\text { tingkat } \\
\text { hipertensi di } \\
\text { posyandu } \\
\text { Lansia di } \\
\text { Kelurahan } \\
\text { Siderejo I } \\
\text { kecamatan } \\
\text { medan kota }\end{array}$ & $\begin{array}{l}\text { analitik } \\
\text { desain } \\
\text { cross } \\
\text { sectional }\end{array}$ & $\begin{array}{ll}\mathrm{N}= & 45 \\
\text { orang } & \\
\text { pada } & \\
\text { lansia } & \end{array}$ & $\begin{array}{l}\text { kuesioner dan } \\
\text { lembar observasi }\end{array}$ & $\begin{array}{l}\text { SPSS } \\
\text { Statistics } \\
\text { mengguna } \\
\text { kan uji } \\
\text { Chi- } \\
\text { Square dan } \\
\text { Fisher's } \\
\text { Exat Tes }\end{array}$ & $\begin{array}{l}\text { Ada hubungan hubungan } \\
\text { olahraga dengan Tingkat } \\
\text { Hipertensi. } \\
\text { Hasil terdapat hubungan } \\
\text { yang signifikan antara } \\
\text { kejadian stres dengan } \\
\text { penyakit hipertensi } \\
\text { Ada Hubungan Pola } \\
\text { Makan Dengan Tingkat } \\
\text { Hipertensi }\end{array}$ \\
\hline 3 & $\begin{array}{l}\text { Wulansar } \\
\mathrm{i}, \quad \mathrm{dkk} \\
(2019) \\
\text { Indonesia }\end{array}$ & $\begin{array}{l}\text { Pengaruh } \\
\text { terapi } \\
\text { beapreasi } \\
\text { (kombinasi } \\
\text { senam otak } \\
\text { dengan } \\
\text { relaksasi } \\
\text { benson) } \\
\text { terhadap } \\
\text { kualitas tidur } \\
\text { pada lanjut } \\
\text { usia dengan } \\
\text { insomnia }\end{array}$ & $\begin{array}{l}\text { quasi } \\
\text { experimen } \\
\mathrm{t} \text { pre-test } \\
\text { post-test } \\
\text { with } \\
\text { control } \\
\text { group }\end{array}$ & $\begin{array}{l}\mathrm{N}=128 \\
\text { responden } \\
\text { yang } \\
\text { terbagi } \\
\text { kedalam } \\
\text { kelompok } \\
\text { eksperime } \\
\mathrm{n} \quad \text { dan } \\
\text { kelompok } \\
\text { kontrol, }\end{array}$ & $\begin{array}{l}\text { Penilaian } \\
\text { Kualitas tidur di } \\
\text { ukur dengan } \\
\text { kuesioner PSQI } \\
\text { (the pittsburgh } \\
\text { sleep quality } \\
\text { index) kemudian } \\
\text { dilakukan } 2 \\
\text { kali pengukuran } \\
\text { yaitu sebelum } \\
\text { dan sesudah } \\
\text { diberikan terapi } \\
\text { Beapreasi }\end{array}$ & $\begin{array}{l}\text { SPSS } \\
\text { Statistics } \\
\text { mengguna } \\
\text { kan uji } \\
\text { wilcoxon } \\
\text { untuk } \\
\text { mengetahu } \\
\text { i pengaruh } \\
\text { terapi } \\
\text { beapreasi } \\
\text { terhadap } \\
\text { kualitas } \\
\text { tidur dari } \\
\text { lansia } \\
\text { yang } \\
\text { mengalami } \\
\text { insomnia } \\
\text { dari setiap } \\
\text { kelompok. } \\
\text { Dan uji } \\
\text { Mann- } \\
\text { whitney } \\
\text { untuk } \\
\text { mengetahu } \\
\text { i } \\
\text { perbedaan } \\
\text { tingkat } \\
\text { depresi } \\
\text { sesudah } \\
\text { intervensi } \\
\text { antara } \\
\text { kelompok } \\
\text { kontrol } \\
\text { dan } \\
\text { intervensi }\end{array}$ & $\begin{array}{l}\text { Hasil penelitian ada } \\
\text { pengaruh yang bermakna } \\
\text { dari pemberian terapi } \\
\text { beapreasi terhadap } \\
\text { peningkatan kualitas } \\
\text { tidur. Intervensi terapi } \\
\text { Beapreasi dapat } \\
\text { meningkatkan kualitas } \\
\text { tidur pada lansia } \\
\text { insomnia }\end{array}$ \\
\hline 1 & 2 & 4 & 5 & 6 & 7 & 8 & 9 \\
\hline
\end{tabular}




\begin{tabular}{|c|c|c|c|c|c|c|c|}
\hline 4 & $\begin{array}{l}\text { Dyah } \\
\text { Putri } \\
\text { Aryati, } \\
\text { dkk } \\
(2019) \\
\text { Indonesia }\end{array}$ & $\begin{array}{l}\text { Application } \\
\text { of } \\
\text { intervention } \\
\text { strategythrou } \\
\text { gh group } \\
\text { processes for } \\
\text { care of stress } \\
\text { in javanese } \\
\text { elderly }\end{array}$ & diskriptif & $\begin{array}{l}\mathrm{N}=30 \\
\text { lansia }\end{array}$ & 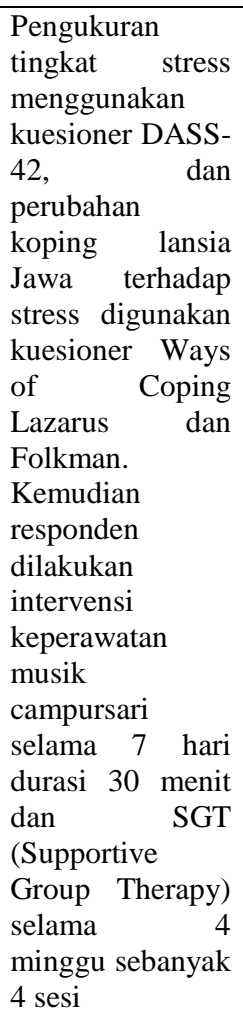 & naratif & $\begin{array}{l}\text { Hasil dari pemberian } \\
\text { intervensi keperawatan } \\
\text { (musik campursari dan } \\
\text { SGT) menunjukkan } \\
\text { adanya penurunan } \\
\text { tingkat stres dan } \\
\text { perubahan koping pada } \\
\text { lansia }\end{array}$ \\
\hline 5 & $\begin{array}{l}\text { Stefanus } \\
\text { Mendes } \\
\text { Kiik, dkk } \\
\text { (2018) } \\
\text { Indonesia }\end{array}$ & $\begin{array}{l}\text { Peningkatan } \\
\text { kualitas hidup } \\
\text { lanjut usia } \\
\text { (lansia) di } \\
\text { kota depok } \\
\text { dengan } \\
\text { latihan } \\
\text { keseimbanga } \\
\text { n }\end{array}$ & $\begin{array}{l}\text { quasi } \\
\text { experimen } \\
\text { t } \\
\text { pre and } \\
\text { post with } \\
\text { control } \\
\text { group } \\
\text { design }\end{array}$ & $\begin{array}{l}\mathrm{N}=30 \\
\text { lansia } \\
\text { kelompok } \\
\text { kontrol } \\
\text { dan } 30 \\
\text { lansiakelo } \\
\text { mpok } \\
\text { perlakuan }\end{array}$ & 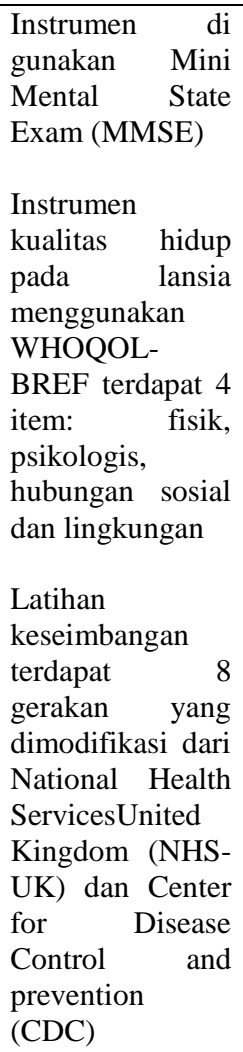 & $\begin{array}{l}\text { SPSS } \\
\text { Statistics } \\
\text { mengguna } \\
\text { kan Paired } \\
\text { t-test } \\
\text { (dependent } \\
\text { t-test) } \\
\text { untuk } \\
\text { membandi } \\
\text { ngkan } \\
\text { kualitas } \\
\text { hidup Pre } \\
\text { dan post } \\
\text { tindakan. } \\
\text { Dan } \\
\text { uji t- } \\
\text { independe } \\
\text { nt } \\
\text { (pooled t- } \\
\text { test) } \\
\text { digunakan } \\
\text { menganali } \\
\text { sa beda } \\
\text { mean pre } \\
\text { dan post }\end{array}$ & $\begin{array}{lr}\text { Hasil } & \text { penelitian } \\
\text { menunjukkan } & \text { bahwa } \\
\text { latihan keseimbangan } \\
\text { berpengaruh } & \text { signifikan, } \\
\text { meningkatkan kualitas } \\
\text { hidup lansia } & \text { (kesehatan } \\
\text { fisik, } & \text { kesehatan } \\
\text { psikologis, hubungan } & \text { hosial dan lingkungan) }\end{array}$ \\
\hline 6 & $\begin{array}{l}\text { Yusriana } \\
\text { (2018) } \\
\text { Indonesia }\end{array}$ & $\begin{array}{l}\text { Kombinasi } \\
\text { teknik } \\
\text { relaksasi } \\
\text { progresif dan } \\
\text { tidur sehat } \\
\text { untuk } \\
\text { meningkatkan } \\
\text { kualitas tidur }\end{array}$ & $\begin{array}{l}\text { quasi } \\
\text { experimen } \\
\mathrm{t} \text { dengan } \\
\text { pendekata } \\
\mathrm{n} \\
\text { Evidence } \\
\text { Based } \\
\text { Practise } \\
\end{array}$ & $\begin{array}{ll}\mathrm{N}= & 56 \\
\text { orang } & \\
\text { lansia. } & \end{array}$ & $\begin{array}{l}\text { Sedangkan untuk } \\
\text { mengukur } \\
\text { kualitas tidur } \\
\text { lansia } \\
\text { menggunakan } \\
\text { instrumen } \\
\text { Pittsburgh } \\
\text { Sleep Quality }\end{array}$ & naratif & $\begin{array}{l}\text { Hasil intervensi ini } \\
\text { menunjukkan pengaruh } \\
\text { dalam meningkatkan } \\
\text { kualitas tidur lansia }\end{array}$ \\
\hline
\end{tabular}




\begin{tabular}{|c|c|c|c|c|c|c|c|}
\hline & & lansia & (EBP) & & $\begin{array}{l}\text { Index (PSQI) } \\
\text { Tindakan } \\
\text { intervensi adalah } \\
\text { teknik relaksasi } \\
\text { progresif }\end{array}$ & & \\
\hline 7 & $\begin{array}{l}\text { Ulfah } \\
\text { Agus } \\
\text { Sukrillah, } \\
\text { dkk } \\
\text { (2017) } \\
\text { Indonesia }\end{array}$ & $\begin{array}{l}\text { Penatalaksana } \\
\text { an non- } \\
\text { farmakologis } \\
\text { reminiscence } \\
\text { group therapy } \\
\text { sebagai upaya } \\
\text { untuk } \\
\text { menurunkan } \\
\text { tingkat } \\
\text { depresi pada } \\
\text { lansia }\end{array}$ & diskriptif & $\begin{array}{l}\mathrm{N}=\text { kader } \\
\text { posyandu } \\
\text { lansia } \\
\text { sejumlah } \\
25 \\
\text { orang }\end{array}$ & $\begin{array}{l}\text { metode pelatihan } \\
\text { dan partisipatif } \\
\text { (pendampingan) } \\
\text { ke lansia dengan } \\
\text { tindakan } \\
\text { intervensi } \\
\text { eminiscence } \\
\text { group therapy }\end{array}$ & naratif & $\begin{array}{l}\text { Kader posyandu lansia } \\
\text { menunjukkan } \\
\text { peningkatan } \\
\text { pengetahuan }(90 \%) \text { dan } \\
\text { keterampilan } \\
(80 \%) \text {. }\end{array}$ \\
\hline 1 & 2 & 4 & 5 & 6 & 7 & 8 & 9 \\
\hline 8 & $\begin{array}{l}\text { Dewa } \\
\text { Gede } \\
\text { Agung } \\
\text { Agus } \\
\text { Setiana, } \\
\text { dkk } \\
\text { (2017) } \\
\text { Indonesia }\end{array}$ & $\begin{array}{l}\text { Pengaruh art } \\
\text { therapy } \\
\text { (terapi } \\
\text { menggambar) } \\
\text { terhadap stres } \\
\text { pada lansia }\end{array}$ & $\begin{array}{l}\text { Quasi } \\
\text { experimen } \\
\mathrm{t} \\
\text { pre and } \\
\text { post with } \\
\text { control } \\
\text { group } \\
\text { design and } \\
\text { post test } \\
\text { nonequiva } \\
\text { lent } \\
\text { control } \\
\text { group }\end{array}$ & $\begin{array}{l}\mathrm{N}=\quad 36 \\
\text { responden } \\
\text { dengan } \\
\text { simple } \\
\text { random } \\
\text { sampling }\end{array}$ & $\begin{array}{l}\text { Instrumen } \\
\text { menggunakan } \\
\text { DASS 42 } \\
\text { Intervensi } \\
\text { digunakan art } \\
\text { therapy } \\
\text { (mengambar) }\end{array}$ & $\begin{array}{l}\text { SPSS } \\
\text { Statistics } \\
\text { mengguna } \\
\text { kan t- test } \\
\text { paired \& t } \\
\text {-test } \\
\text { independe } \\
\text { nt }\end{array}$ & $\begin{array}{l}\text { Hasil penelitian terdapat } \\
\text { pengaruh } \\
\text { art therapy (terapi } \\
\text { menggambar) terhadap } \\
\text { stres pada lansia }\end{array}$ \\
\hline 9 & $\begin{array}{l}\text { Olivia } \\
\text { Dwi } \\
\text { Kumala, } \\
\text { dkk } \\
(2017) \\
\text { Indonesia }\end{array}$ & $\begin{array}{l}\text { Efektivitas } \\
\text { Pelatihan } \\
\text { Dzikir dalam } \\
\text { Meningkatka } \\
\text { n Ketenangan } \\
\text { Jiwa } \\
\text { pada Lansia } \\
\text { Penderita } \\
\text { Hipertensi }\end{array}$ & $\begin{array}{l}\text { Quasi } \\
\text { experimen } \\
\mathrm{t} \\
\text { desain } \\
\text { control } \\
\text { one group } \\
\text { pretestpos } \\
\text { ttest }\end{array}$ & $\begin{array}{ll}\mathrm{N}= & 8 \\
\text { lansia } & \end{array}$ & $\begin{array}{l}\text { Intervensi } \\
\text { digunakan } \\
\text { pelatihan Dzikir }\end{array}$ & $\begin{array}{l}\text { SPSS } \\
\text { Statistics } \\
\text { mengguna } \\
\text { kan } \\
\text { wilcoxon } \\
\text { rank test }\end{array}$ & $\begin{array}{l}\text { Hasil penelitian terdapat } \\
\text { adanya perbedaan } \\
\text { tingkat ketenangan jiwa } \\
\text { yang signifikan sebelum } \\
\text { menerima pelatihan dan } \\
\text { setelah diberi pelatihan. }\end{array}$ \\
\hline $\begin{array}{l}1 \\
0 .\end{array}$ & $\begin{array}{l}\text { Goren } \\
\text { Amir } \\
\text { Montgom } \\
\text { ery } \\
\text { William, } \\
\text { dkk } \\
(2016) \\
\text { - } \\
\text { merika }\end{array}$ & $\begin{array}{l}\text { Impact of } \\
\text { caring for } \\
\text { persons with } \\
\text { Alzheimer's } \\
\text { disease or } \\
\text { dementia on } \\
\text { caregivers' } \\
\text { health } \\
\text { outcomes: } \\
\text { findings from } \\
\text { a community } \\
\text { based survey } \\
\text { in Japan }\end{array}$ & $\begin{array}{l}\text { analitik } \\
\text { desain }\end{array}$ & $\begin{array}{l}\mathrm{N}=55060 \\
\text { responden } \\
, \quad \mathrm{di} \\
\text { bandingk } \\
\text { an non- } \\
\text { caregiver } \\
(\mathrm{n} \quad= \\
53758) \text {, } \\
\text { caregiver } \\
(\mathrm{n} \quad= \\
1302)=\end{array}$ & $\begin{array}{l}\text { Instrumen } \\
\text { Baseline } \\
\text { comorbidities, } \\
\text { Sociodemographi } \\
\text { cs, health } \\
\text { characteristics } \\
\text { and behaviors, } \\
\text { Comorbidities, , } \\
\text { Depression , } \\
\text { Work } \\
\text { productivity, } \\
\text { HRQoL, } \\
\text { Healthcare } \\
\text { resource } \\
\text { utilization, }\end{array}$ & $\begin{array}{l}\text { SPSS } \\
\text { Statistics } \\
\text { mengguna } \\
\text { kan Chi- } \\
\text { square } \\
\text { tests } \\
\text { dan t tests } \\
\text { (means) }\end{array}$ & $\begin{array}{l}\text { Pasien lansia demensia } \\
\text { di Jepang mengalami } \\
\text { HRQoL yang secara } \\
\text { signifikan lebih buruk } \\
\text { dan risiko komorbiditas } \\
\text { yang lebih besar } \\
\text { mengalami penurunan } \\
\text { produktivitas. }\end{array}$ \\
\hline $\begin{array}{l}1 \\
1\end{array}$ & $\begin{array}{l}\text { Fitria } \\
\text { Andiny, } \\
\text { dkk } \\
(2016) \\
\text { - I } \\
\text { ndonesia }\end{array}$ & $\begin{array}{l}\text { Halma } \\
\text { Traditional } \\
\text { Game } \\
\text { Prevent to } \\
\text { Cognitive } \\
\text { Impairment } \\
\text { Progressivity } \\
\text { on Elderly } \\
\text { with } \\
\text { Dementia }\end{array}$ & $\begin{array}{l}\text { quasi } \\
\text { experimen } \\
\mathrm{t} \\
\text { pre and } \\
\text { post with } \\
\text { control } \\
\text { group } \\
\text { design }\end{array}$ & $\begin{array}{l}\mathrm{N}=\quad 18 \\
\text { lansia } \\
\text { simple } \\
\text { random } \\
\text { sampling. }\end{array}$ & $\begin{array}{l}\text { Instrumen } \\
\text { penelitian untuk } \\
\text { penilain kognitif } \\
\text { menggunakan } \\
\text { Montreal } \\
\text { Cognitive } \\
\text { Asessment-INA } \\
\text { (MoCA-Ina) } \\
\text { Tindakan } \\
\text { intervensi } \\
\text { permaianan }\end{array}$ & $\begin{array}{l}\text { SPSS } \\
\text { Statistics } \\
\text { mengguna } \\
\text { kan uji } \\
\text { statistic } \\
\text { Karakterist } \\
\text { ik Lansia } \\
\text { Paired T- } \\
\text { Test dan } \\
\text { Independe } \\
\text { nt T-Test }\end{array}$ & $\begin{array}{l}\text { Hasilnya menunjukkan } \\
\text { bahwa halma merupakan } \\
\text { terapi yang efektif secara } \\
\text { perlahan-lahan } \\
\text { mengurangi } \\
\text { progressivitiy dari } \\
\text { penurunan kognitif } \\
\text { lansia dengan demensia. }\end{array}$ \\
\hline
\end{tabular}




\begin{tabular}{|c|c|c|c|c|c|c|c|}
\hline & & & & & Halma & & \\
\hline $\begin{array}{l}1 \\
2\end{array}$ & $\begin{array}{l}\text { Simon } \\
\text { Coulton, } \\
\text { Stephen } \\
\text { Clift,dkk } \\
(2015) \\
\text { ritish }\end{array}$ & $\begin{array}{l}\text { Effectiveness } \\
\text { and cost- } \\
\text { effectiveness } \\
\text { of community } \\
\text { singing on } \\
\text { mental } \\
\text { health-related } \\
\text { quality of life } \\
\text { of older } \\
\text { people: } \\
\text { randomised } \\
\text { controlled } \\
\text { trial }\end{array}$ & $\begin{array}{l}\text { randomize } \\
\mathrm{d} \\
\text { controlled } \\
\text { trial } \\
\text { design } \\
\text { dengan } \\
\text { control } \\
\text { group }\end{array}$ & $\begin{array}{l}\mathrm{N}=258 \\
\text { lansia, } \\
\text { dibagi } \\
\text { dua grup } \\
\text { perlakuan } \\
\text { singing } \\
\text { group } 131 \\
\text { lansia , } \\
\text { sedangka } \\
\text { n kontrol } \\
\text { melakuka } \\
\text { n } \\
\text { aktivitas } \\
\text { sehari- } \\
\text { hari } 127 \\
\text { lansia }\end{array}$ & $\begin{array}{l}\text { Tindakan } \\
\text { kelompok } \\
\text { intervensi } \\
\text { singing group } \\
\text { dengan genre } \\
\text { bervariasi lama } \\
14 \quad \text { minggu } \\
\text { selama } 90 \text { menit } \\
\text { selama } 6 \text { bulan } \\
\text { dan grup kontrol } \\
\text { tetap melakukan } \\
\text { aktivitas sehari- } \\
\text { hari kemudian di } \\
\text { ukur instrument } \\
\text { mental health- } \\
\text { related quality of } \\
\text { life assessed by } \\
\text { the York SF12 }\end{array}$ & $\begin{array}{l}\text { Cost- } \\
\text { effectivene } \\
\text { ss } \\
\text { acceptabili } \\
\text { ty curve } \\
\text { comparing } \\
\text { the } \\
\text { probability } \\
\text { of cost- } \\
\text { effectivene } \\
\text { ss for } \\
\text { interventio } \\
\mathrm{n} \text { and } \\
\text { control at } \\
\text { different } \\
\text { QALY } \\
\text { valuations. }\end{array}$ & $\begin{array}{l}\text { singing group kelompok } \\
\text { komunitas tampaknya } \\
\text { memiliki pengaruh yang } \\
\text { signifikan berpengaruh } \\
\text { pada kualitas hidup, } \\
\text { kegelisahan dan } \\
\text { gangguan mental yang } \\
\text { berhubungan dengan } \\
\text { kesehatan mental } \\
\text { depresi, dan itu mungkin } \\
\text { merupakan intervensi } \\
\text { yang berguna } \\
\text { dipertahankan } \\
\text { dan meningkatkan } \\
\text { kesehatan mental lansia. }\end{array}$ \\
\hline $\begin{array}{l}1 \\
3\end{array}$ & $\begin{array}{l}\text { Stobbe, } \\
\text { Jolanda, } \\
\text { André, } \\
\text { Wierdsm } \\
\text { a, dkk } \\
(2014) \\
\text { etherland } \\
\text { s }\end{array}$ & $\begin{array}{l}\text { The } \\
\text { effectiveness } \\
\text { of assertive } \\
\text { community } \\
\text { treatment for } \\
\text { elderly } \\
\text { patients with } \\
\text { severe mental } \\
\text { illness: a } \\
\text { randomized } \\
\text { controlled } \\
\text { trial }\end{array}$ & $\begin{array}{l}\text { randomize } \\
\mathrm{d} \\
\text { controlled } \\
\text { trial } \\
\text { design } \\
\text { dengan } \\
\text { control } \\
\text { group }\end{array}$ & $\begin{array}{l}\mathrm{N}=62 \\
\text { lansia } \\
\text { rawat } \\
\text { jalan } \\
\text { dengan } \\
\text { severe } \\
\text { mental } \\
\text { illness } \\
\text { (SMI), } \\
\text { dengan } \\
\text { random } \\
\text { sampling } \\
\text { dengan } \\
\text { dibagi } \\
\text { dua grup } \\
32 \\
\text { perlakuan } \\
\text { Assertive } \\
\text { communit } \\
\text { y treat- } \\
\text { ment } \\
\text { (ACT) } \\
\text { dan } \\
\text { sisanya } \\
\text { sebagai } \\
\text { grup } \\
\text { kontrol } \\
\text { dan } \\
\text { treatment } \\
\text { as usual } \\
\text { (TAU) } \\
\text { sebanyak } \\
30 \\
\end{array}$ & $\begin{array}{l}\text { Di beri tindakan } \\
\text { kelompok } \\
\text { intervensi (ACT) } \\
\text { dengan } \\
\text { kelompok } \\
\text { kontrol TAU } \\
\text { kemudian di } \\
\text { Observasi } \\
\text { dengan } \\
\text { instrument The } \\
\text { Dutch version of } \\
\text { the Health of the } \\
\text { Nation Out- } \\
\text { come Scales for } \\
\text { elderly people } \\
\text { (HoNOS65+) di } \\
\text { gunakan untuk } \\
\text { menilai the } \\
\text { severity of } \\
\text { psychosocial } \\
\text { problems } \\
\text { sebanyak } 12 \text { item } \\
\text { dan Dartmouth } \\
\text { Assertive } \\
\text { Community } \\
\text { Treatment Scale } \\
\text { (DACTS), } \\
\text { kemudian hasil } \\
\text { di bandingkan } \\
\text { antara kelompok } \\
\text { intervensi dan } \\
\text { kontrol }\end{array}$ & $\begin{array}{l}\text { SPSS } \\
\text { Statistics } \\
\text { dengan uji } \\
\text { mengguna } \\
\text { kan Chi- } \\
\text { Square }\end{array}$ & $\begin{array}{l}\text { Hasil menunjukkan } \\
\text { bahwa ACT untuk } \\
\text { pasien lanjut usia dengan } \\
\text { SMI dalam masa } \\
\text { pengobatan rawat jalan } \\
\text { di komunitas di katakan } \\
\text { berhasil. }\end{array}$ \\
\hline $\begin{array}{l}1 \\
4\end{array}$ & $\begin{array}{l}\text { Ghodsbin } \\
\text { Fariba, } \\
\text { Sharif } \\
\text { Zahra } \\
\text { Ahmadi, } \\
\text { dkk } \\
(2014) \\
\text { - } \\
\text { ran }\end{array}$ & $\begin{array}{l}\text { The Effects } \\
\text { of Laughter } \\
\text { Therapy on } \\
\text { General } \\
\text { Health of } \\
\text { Elderly } \\
\text { People } \\
\text { Referring to } \\
\text { Jahandidegan } \\
\text { Community } \\
\text { Center in } \\
\text { Shiraz, Iran, } \\
\text { 2014: A } \\
\text { Randomized } \\
\text { Controlled }\end{array}$ & $\begin{array}{l}\text { randomize } \\
\mathrm{d} \\
\text { controlled } \\
\text { trial } \\
\text { design } \\
\text { dengan } \\
\text { control } \\
\text { group }\end{array}$ & $\begin{array}{l}\mathrm{N}=72 \\
\text { lansia, } \\
\text { dibagi } \\
\text { dua grup } \\
36 \\
\text { perlakuan } \\
\text {, } \\
\text { sedangka } \\
\text { n kontrol } \\
36\end{array}$ & $\begin{array}{l}\text { Di beri tindakan } \\
\text { kelompok } \\
\text { intervensi } \\
\text { Laughter } \\
\text { Therapy secara } \\
\text { teratur selama } 2 \\
\text { sesi lama } 90 \\
\text { menit / minggu } \\
\text { selama } 6 \text { minggu } \\
\text { sedangkan } \\
\text { kelompok } \\
\text { kontrol dengan } \\
\text { publik health } \\
\text { kemudian di ukur } \\
\text { dengan }\end{array}$ & $\begin{array}{l}\text { SPSS } \\
\text { software, } \\
\text { version } 21 . \\
\text { Non- } \\
\text { parametric } \\
\text { tests } \\
\text { including } \\
\text { Wilcoxon } \\
\text { and Mann- } \\
\text { Whitney, } \\
\text { dengan } \\
\text { normality } \\
\text { Kolmogor } \\
\text { ov- } \\
\text { Smirnov } \\
\end{array}$ & $\begin{array}{lr}\text { Hasil statistically } \\
\text { significant correlation } \\
\text { antara laughter therapy } \\
\text { program and factors } \\
\text { general health, somatic } \\
\text { symptoms, insomnia and } \\
\text { anxiety. Namun, tidak } \\
\text { ada korelasi yang } \\
\text { signifikan secara statistik } \\
\text { antara laughter therapy } \\
\text { dengan faktor social } \\
\text { dysfunction } \\
\text { depression , sehingga } \\
\text { dapat disimpulkan } \\
\text { laughter therapy dapat }\end{array}$ \\
\hline
\end{tabular}




\begin{tabular}{|l|l|l|l|l|l|}
\hline & Trial & & instrument & & $\begin{array}{l}\text { meningkatkan general } \\
\text { health dan subtansi- } \\
\text { subtansinya pada lansia } \\
\text { gan berada di komunitas } \\
\text { Questionnaire } \\
\text { (GHQ-28) and } \\
\text { demographic } \\
\text { questionnaire }\end{array}$
\end{tabular}

\section{Pembahasan}

Kesehatan mental merupakan komponen mendasar dari definisi kesehatan. Kesehatan mental yang baik memungkinkan orang untuk menyadari potensi mereka, mengatasi tekanan kehidupan yang normal, bekerja secara produktif, dan berkontribusi pada komunitas mereka (WHO, 2013). Para lansia, bersifat kronis dan multipatologis, serta dalam penanngannya memerlukan waktu lama dan membutuhkan banyak biaya cukup besar karena pandangan atau persepsi yang salah dari keluarga, masyarakat tersebut tentang lansia maka seringkali keadaan fisik, mental, maupun kebutuhan usia lanjut tidak terpenuhi dengan baik (K, Iwan, 2019)

Upaya memberikan pelayanan kesehatan baik fisik dan jiwa diberikan kepada seluruh lapisan masyarakat merupakan hak asasi manusia yang melibatkan peran dari berbagai sector di masyarakat termasuk seluruh jajaran pemerintah dan lapisan masyarakat, tokoh agama, tokoh adat, tokoh masyarakat, organisasi masyarakat, organisasi profesi, dan dunia usaha dan swasta (Pusat Komunikasi Publik Sekretariat Jenderal Kementerian Kesehatan RI, 2014)

Permasalahan yang sering di lami oleh lansia seperti permasalahn jiwa psikososial adanya stress, dimensia, depresi, gangguan tidur, penurunan fisik dapat mempengaruhi kesejahteraan hidup (Wijoyo and Daulima, 2020). Lansia yang berada di lingkungan masyarakat untuk meningkatkan kualitas hidup lansia dari segi kesehatan fisik, kesehatan psikologis, hubungan sosial dan lingkungan diperlukan pendekatan intervensi keperawatan seperti latihan keseimbangan berpengaruh signifikan terhadap kualitas hidup lansia (Kiik, Sahar and Permatasari, 2018). Dukungan sosial dalam kegiatan terapi aktifitas kelompok terapuetik dapat mendukung beradapatasi dengan perubahan sehingga merasakan sejahtera dan tenang dalam menghadapi hidup pada aspek: biologis, seksual, kognitif, sosial, spitual (Wijoyo and Daulima, 2020). Terdapat beberapa pendekatan intervensi kesehatan jiwa dapat dilakukan secara individual dan kelompok (Stuart, 2016).

Dampak penurunan fisik pada lansia merupakan suatu proses menghilangnya secara perlahan-lahan kemampuan jaringan untuk memperbaiki diri atau mengganti diri dan mempertahankan, Salah satu penyebab peningkatan tekanan darah pada pasien hipertensi adalah stres. Stres merupakan suatu tekan fisik maupun psikis yang tidak menyenangkan Stres dapat merangsang kelenjar anak ginjal melepaskan hormon adrenalin dan memacu jantung berdenyut lebih cepat dan kuat, sehingga tekanan darah akan meningkat. (Keliat, B.A, 2015).

Lansia dengan hipertensi kronis dapat menimbulkan komplikasi pada organ tubuh yaitu otak, mata, jantung, pembuluh darah arteri, serta ginjal. Sebagai dampak terjadinya komplikasi hipertensi berfek kualitas hidup penderita menjadi rendah dan kemungkinan terburuknya adalah terjadinya kematian. Untuk mencegah komplikasi hipertensi pada lansia di masyarakat maka diperlukan preventive seperti kegiatan olahraga secara teratur yang bersifat rekreasi, sehingga tidak menimbulkan rasa jenuh untuk lansia. dengan gerakan tertentu yang melibatkan otot tubuh akan dapat menjaga kekuatan otot, fungsi persendian, pembuluh darah tetap elastis dan tetap terbuka, sehingga memperlancar aliran darah ke bagian-bagian tubuh kita, membantu melatih pengembangan paru-paru (Kurniawan, 2019).

Lansia dengan pendekatan spiritual yang khususnya beragama Islam dengan terapi dzikir dapat berefek ke ketenangan jiwa yang berefek terhadap penurunan stressor sehingga mempengaruhi kestabilan tekanan darah (Kumala, Kusprayogi and Nashori, 2017).

Terapi kelompok teraupeutik (TKT) pada lansia diharapkan dengan dukungan sosoal dario lingkungan sekitarnya dapat beradapatasi dengan perubahan sehingga merasakan sejahtera dan tenang dalam menghadapi hidup pada aspek: biologis, seksual, kognitif, sosial, spitual (Wijoyo and 
Daulima, 2020). Lansia yang berada di komunitas yang mengalami stress dapat dilakukan tindakan keperawatan jiwa didukung oleh beberapa penelitian dari Aryati and Widyastuti (2019) mengatakan bahwa hasil dari pemberian intervensi keperawatan Supportive Group Therapy (SGT) di kombinasikan dengan musik campursari terdapat efek dapat penurunan tingkat stress . Pendapat tersebut didukung oleh Dewa Gede, Agung Agus S, Cristin Wiyani (2017) mengatakan bahwa hasil penelitian terdapat pengaruh art therapy (terapi menggambar) terhadap stres pada lansia.

Tindakan keperawatan jiwa pada lansia dengan Singing group di kelompok komunitas tampaknya memiliki pengaruh yang signifikan berpengaruh pada kualitas hidup, kegelisahan dan gangguan mental yang berhubungan dengan kesehatan mental depresi, dan itu mungkin merupakan intervensi yang berguna untuk dipertahankan dan meningkatkan kesehatan mental lansia (Coulton et al., 2015). Pendapat tersebut didukung oleh Sukrillah et al., (2018) menjelaskan bahwa hasil tindakan keperawatan reminiscence group therapy dapat meningkatkann koping untuk menurunkan tingkat depresi pada lansia.

Peran Caregiver sebagai pendamping orang terdekat yang memberikan asuhan keperawatan sehari-hari yang berada di lingkungan dekat lansia dengan Dimensia di komunitas dapat berefek meringankan gangguan jiwanya seperti gannguan interaksi sosial, depresi dari pada lansia yang hidup sendiri tanpa caregiver lebih rentan terkena gangguan jiwa (Goren et al., 2016). Pendapat tersebut didukung oleh Andiny et al., (2016) menjelaskan bahwa bahwa permainan halma merupakan terapi yang efektif secara perlahanlahan mengurangi progressivitiy dari penurunan kognitif pada lansia dengan demensia.

Lansia yang berada di komunitas yang mengalami permasalahan tidur dapat di tangani dengan tindakan keperawatan jiwa seperti Kombinasi teknik relaksasi progresif dan tidur sehat (Yusriana, 2018) dan beapreasi (kombinasi senam otak dengan relaksasi benson) (Wulansari, Mustain and Ismiriyam, 2019). Di dukung Ghodsbin and Ahmadi (2014) mengatakan bahwa hasil penelitian disimpulkan laughter therapy program terdapat hubungan bermakna pada factors general health, somatic symptoms, insomnia and anxiety, laughter therapy dapat meningkatkan general health pada lansia yan berada di komunitas, namun tidak ada korelasi signifikan antara laughter therapy dengan faktor social dysfunction and depression..

Lansia di komunitas dengan status sehat maupun sakit yang mendapatkan terapi pengobatan fisik secara tidak langsung dapat mempengaruhi psikoligisnya dikarenakan terdapat efek saling terkaitan antara kesehatan mental terhadap imunitas tubuh (Coulton et al., 2015). Maka kegitan intervensi kesehatan jiwa yang dilakukan secara kelompok dapat berpengaruh pada peran dukungan sosial lingkungan sekitarnya seperti ACT Assertive community treat- ment (ACT) untuk pasien lanjut usia rawat jalan dengan SMI (dengan severe mental illness) dalam masa pengobatan rawat jalan di komunitas di katakan berhasil menciptkan saling memperkuat hubungan dukungan sosial (Stobbe et al., 2014). .

Hal paling menarik dari seluruh penelitian ini berdasarkan 14 hasil penelitian di atas kesehatan jiwa pada lansia secara emosional, psikologis dan social terlihat dari hubungan interpersonal yang berkaitan dengan perilaku dan koping yang efektif, dapat membantu dirinya menentukan bagaimana berespon dan bersikap yang tepat terhadap segala situasi yang terjadi (Ghodsbin and Ahmadi, 2014) .

Intervensi keperawatan jiwa melatih kemampuan terapi perilaku dan suatu proses dimana lansia di komunitas dapat di gunakan sehingga mengatasi gangguan emosianal dan kejiwaannya

\section{Kesimpulan}

Meningkatkan status kesehatan lansia dengan memberikan pelayanan intervensi keperawatan kesehatan yang komperenhenisif baik fisik dan kesehatan jiwa lansia dengan berbagai pendekatan bisa di upayakan yaitu upaya mengatasi stress (olah raga, SGT, reminiscence group therapy, art therapy), terapi kelompok teraupeutik (singging grup, Assertive community treatment, laughter therapy program,latihan keseimbangan, dzikir, permaian halma), meningkatkan kualitas tidur lansia dengan tindakan relaksasi progresif dan terapi beapreasi. Beberapa tindakan keperawatan jiwa pada lansia yang telah di bahas di atas dapat di terapkan dalam pelayanan keperawatan kesehatan jiwa komunitas sehingga di harapkan dapat meningkatkan jumlah lansia harapan hidup, 
dapat meningkatkan pengetahuan, sikap dan perilaku positif lansia, dapat meningkatkan mutu dan derajat kesehatan lansia dengan dukungan penuh dari masyarakat.

\section{DAFTAR PUSTAKA}

Andiny, F. et al. (2016) 'Permainan halma mencegah progresiftas kerusakan kognitif pada lansia demensia', Jurnal Keperawatan, $I X(2)$, pp. 71-75.

Aryati, D. P. and Widyastuti, R. H. (2019) 'Aplikasi strategi intervensi melalui proses kelompok dalam penatalaksanaan stres pada lansia Jawa', JPPM (Jurnal Pengabdian dan Pemberdayaan Masyarakat), 3(2), p. 205. doi: 10.30595/jppm.v3i2.4794.

Ayuningtyas, D. and Rayhani, M. (2018) 'Analisis situasi kesehatan mental pada masyarakat di indonesia dan strategi penanggulangannya', Jurnal Ilmu Kesehtan Masyarakat, 9(1), pp. 1-10.

Coulton, S. et al. (2015) 'Effectiveness and costeffectiveness of community singing on mental health-related quality of life of older people: randomised controlled trial', pp. 250-255. doi: 10.1192/bjp.bp.113.129908.

Dewa Gede, Agung Agus S, Cristin Wiyani, R. E. (2017) 'Pengaruh art therapy ( terapi menggambar) terhdap stress pada lansia', Jurnal Kebidanan dan Keperawatan, 13(2), pp. 192-202.

Efendi, F. M. (2016) Keperawatan kesehatan komunitas. Jakarta Indonesia: Salemba Medika.

Fauzia, Y. and Paramita, A. (2016) 'Pelayanan kesehatan mental dalam hubungannya dengan disabilitas dan gaya hidup masyarakat Indonesia ( analisis lanjut

Riskesdas 2007 dan 2013 ) ( mental health services disability and life style of Indonesian )', Buletin penelitian sistem kesehatan, 19(1 Januari), pp. 99-107.

Ghodsbin, F. and Ahmadi, Z. S. (2014) 'O riginal A rticle The Effects of Laughter Therapy on General Health of Elderly People Referring to Jahandidegan Community Center in Shiraz ', IJCBNM, 3(1), pp. 31-38.

Goren, A. et al. (2016) 'Impact of caring for persons with Alzheimer', $s$ disease or dementia on caregivers 'health outcomes: findings from a community based survey in Japan', BMC Geriatrics. BMC Geriatrics, 16(122), pp. 1-12. doi: 10.1186/s12877016-0298-y.

$K$, Iwan, D. (2019) 'Gambaran persepsi masyarakat tentang manfaat posyandu Lansia di kelurahan naioni rw 04 kecamatan alak kota kupang', CHMK Health Journal, 3(1), pp. 25-30.
Keliat, B.A, dkk (2015) Standar asuhan keperawatan jiwa diagnosa sehat, resiko dan gangguan.

Keliat, Budi Anna, Panjaitan, Ria utami, Riasmini, M. (2010) Manajement keperawatan jiwa komunitas desa siaga:CMHN(Intermediate Course). 1st edn. Jakarta Indonesia: EGC.

Kumala, O. D., Kusprayogi, Y. and Nashori, F. (2017) 'Efektivitas pelatihan dzikir dalam meningkatkan ketenangan jiwa pada lansia penderita hipertensi', Psympathic: Jurnal Ilmiah Psikologi, 4(1), pp. 55-66. doi: 10.15575/psy.v4i1.1260.

Kurniawan, I. (2019) 'Hubungan Olahraga , Stress dan Pola Makan dengan Tingkat Hipertensi di Posyandu Lansia di Kelurahan Siderejo I Kecamatan Medan Kota Artikel Info Diterima: November 2018 Revisi: Desember 2018 Online: Januari 2019', Journal of health science and pysiotherapy, 1(1), pp. 10-17.

Pusat Komunikasi Publik Sekretariat Jenderal Kementerian Kesehatan RI (2014) Stop Stigma dan Diskriminasi Terhadap Orang dengan Gangguan Jiwa (ODGJ). Availableat:http://www.depkes.go.id/article /print/201410270011/ stop-stigma-dandiskriminasi-terhadap-orang- dengangangguan-jiwa-odgj.html.

Rusdi, E. R. (2013) 'Hubungan Peran Kader Dengan Pelaksanaan Kegiatan Posyandu Lansia ('Stobbe, J. et al. (2014) 'The effectiveness of assertive community treatment for elderly patients with severe mental illness: a randomized controlled trial'.

Sukrillah, U. A. et al. (2018) 'Penatalaksanaan non-farmakologis reminiscence group therapy sebagai upaya untuk menurunkan tingkat depresi pada lansia', Link, 13(2), p. 38. doi: 10.31983/link.v13i2.2925.

WHO (2013) Mental Health Action Plan 2013 2020. Geneva: World Health Organization.

Wijoyo, E. B. and Daulima, N. H. . (2020) 'Optimalisasi integritas diri melalui terapi kelompok teraupetiklLansia: studi kasus', Jurnal JKFT, 5(2), p. 26. doi: 10.31000/jkft.v5i2.3919.

Wulansari, W., Mustain, M. and Ismiriyam, F. V. (2019) 'Pengaruh terapi beapreasi (kombinasi senam otak dengan relaksasi Benson) terhadap kualitas tidur pada lanjut usia dengan insomnia', Jurnal Perawat Indonesia, 3(1), p. $8 . \quad$ doi: 10.32584/jpi.v3i1.199.

Yusriana (2018) 'Kombinasi teknik relaksasi progresif dan tidur sehat untuk meningkatkan kualitas tidur lansia', Menara Ilmu, XII(80), pp. 137-145. 